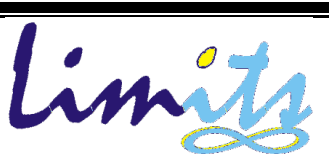

Limits: Journal of Mathematics and Its Applications

E-ISSN: 2579-8936

P-ISSN: 1829-605X

Vol. 16, No. 2, Desember 2019, 147-157

DOI: http://dx.doi.org/10.12962/limits.v16i2.5818

\title{
Penerapan Metode Runge-Kutta dan Iterasi Variasional dalam Simulasi Transmisi Tuberkulosis
}

\author{
Gabariela Purnama Ningsi ${ }^{1}$, Sudi Mungkasi ${ }^{2}$ \\ ${ }^{1}$ Program Studi Pendidikan Matematika, Fakultas Keguruan dan Ilmu Pendidikan, \\ Universitas Katolik Indonesia Santu Paulus Ruteng, Manggarai, Flores, Nusa Tenggara Timur, Indonesia \\ ${ }^{2}$ Program Studi Matematika, Fakultas Sains dan Teknologi, Universitas Sanata Dharma, \\ Mrican, Tromol Pos 29, Yogyakarta 55002, Indonesia \\ e-mail: ningsilatib5@gmail.com, sudi@usd.ac.id
}

\begin{abstract}
Abstrak
Matematika dapat diterapkan untuk menyelesaikan berbagai masalah dalam kehidupan sehari-hari. Salah satu masalah yang dapat diselesaikan dengan menerapkan matematika adalah tentang laju transmisi penyakit menular. Penelitian ini bertujuan untuk menyelesaikan sistem persamaan laju transmisi Tuberkulosis (TB) model epidemi Susceptible-Infected-Recovered (SIR) yang berbentuk sistem persamaan diferensial nonlinear. Metode yang digunakan untuk menyelesaikan sistem persamaan diferensial ini adalah metode Runge-Kutta orde empat (RK4) dan metode iterasi variasional (VIM) standar. Metode penelitian yang digunakan dalam penelitian ini adalah metode numerik yang dilengkapi praktik simulasi menggunakan MATLAB. Hasil penelitian adalah bahwa: pertama, metode RK4 menghasilkan solusi model SIR yang realistis untuk sebarang waktu; kedua, selisih antara solusi RK4 dan solusi VIM cukup kecil untuk nilai waktu yang cukup kecil; ketiga, waktu yang cukup besar mengakibatkan solusi VIM menjadi tidak realistis.
\end{abstract}

Kata Kunci: metode Runge-Kutta, iterasi variasional, persamaan diferensial, transmisi Tuberkulosis

\begin{abstract}
Mathematics can be applied to solve a number of problems in everyday life. One problem that can be solved by applying mathematics is that of the rate of transmission of infectious diseases. This study aims to resolve the rate of Tuberculosis (TB) transmission of the Susceptible-Infected-Recovered (SIR) epidemic model in the form of a system of non-linear differential equations. The methods to solve this system of differential equations are the fourth-order Runge-Kutta method (RK4) and the standard variational iteration method (VIM). The research method in this study is numerical method which is completed with simulations using MATLAB. Our results are: first, the RK4 method produces a realistic solution to the SIR model for any time value; second, the difference between the RK4 solution and the VIM solution is sufficiently small for sufficiently small time value; third, sufficiently large time value leads to that the VIM solution becomes unrealistic.
\end{abstract}

Keywords: Runge-Kutta method, variational iteration, differential equation, Tuberculosis transmission

\section{Pendahuluan}

Persamaan diferensial sudah menjadi salah satu kajian ilmu matematika yang tidak hanya digunakan dalam matematika itu sendiri, tetapi juga dapat digunakan untuk menyelesaikan masalah dalam kehidupan sehari-hari, serta masalah dalam bidang kajian ilmu yang lain yaitu ekonomi, industri, fisika, biologi, ilmu komputer, dll. [1-3]. Persamaan diferensial biasa nonlinear merupakan suatu persamaan diferensial yang memenuhi sifat bahwa fungsi yang tidak 
diketahui hanya bergantung pada satu variabel bebas, dan sistem tersebut memuat suku nonlinear atas fungsi atau turunan fungsi yang tidak diketahui.

Salah satu masalah dalam kehidupan sehari-hari serta dalam bidang biologi yang dapat dimodelkan ke dalam bentuk persamaan diferensial nonlinear adalah masalah tentang transmisi penyakit menular. Masalah ini dapat dibawa ke dalam model Susceptible-InfectedRecovered (SIR). Dalam model SIR [4, 5], populasi yang diteliti dikategorikan dalam tiga kelompok yang diberi label $S, I$, dan $R$. Di sini, $S(t)$ merupakan kelompok individu yang rentan (Susceptible) terhadap penyakit yaitu orang yang belum terinfeksi pada saat waktu $t ; I(t)$ merupakan kelompok individu yang terinfeksi (Infected) pada saat waktu $t$, kelompok infeksi ini mampu menularkan penyakit kepada kelompok rentan jika terjadi kontak langsung; $R(t)$ merupakan kelompok individu yang sudah pernah terinfeksi dan sembuh (Recovered) dari penyakit tersebut, serta tidak akan terinfeksi lagi (sembuh permanen).

Makalah ini akan menyelesaikan model SIR transmisi Tuberkulosis (TB) dengan menggunakan metode Runge-Kutta orde empat (RK4) dan metode iterasi variasional (VIM) standar. Metode Runge-Kutta merupakan salah satu metode numerik yang dapat digunakan untuk menyelesaikan masalah nilai awal. Metode iterasi variasional merupakan suatu metode yang digunakan untuk menyelesaikan persamaan diferensial linear dan nonlinear yang akan memperkirakan solusi dengan cepat dan mudah [6, 7]. Hasil simulasi kedua metode tersebut akan dianalisis apakah realistis ataukah tidak.

\section{Metode Penelitian}

Penelitian ini mempelajari model transmisi TB dan simulasi numeriknya. Model TB yang dipelajari adalah model yang telah dibuat oleh Side [8]. Untuk menyelesaikan model tranmisi TB, mula-mula model matematika dikonstruksi ke dalam bentuk konsep metode numerik [9], yang dalam hal ini adalah metode RK4 dan VIM. Simulasi numerik dilakukan dengan menggunakan kedua metode tersebut yang diprogram ke dalam perangkat lunak MATLAB.

\subsection{Model SIR Transmisi TB}

Side [8] telah membentuk sistem persamaan diferensial nonlinear untuk memodelkan transmisi TB dengan menggunakan konsep SIR sebagai berikut:

$$
\begin{gathered}
\frac{d x}{d t}=\mu_{h}-\beta_{h} x-\gamma \beta_{h} x y-\mu_{h} x \\
\frac{d y}{d t}=\beta_{h} x-\alpha y
\end{gathered}
$$




$$
\frac{d z}{d t}=\gamma \beta_{h} x y-\eta z
$$

dimana

$$
x(t)=\frac{S_{h}}{N_{h}}, \quad y(t)=\frac{I_{h}}{N_{h}}, \quad z(t)=\frac{I_{i}}{N_{h}}
$$

dan

$$
\alpha=\mu_{h}+\delta_{h}, \quad \eta=\mu_{h}+\varphi_{h}, \quad N_{h}=S_{h}+I_{h}+I_{i}+R_{h}
$$

serta keterangan variabel dan parameter diringkas dalam Tabel 1.

Tabel 1. Variabel dan parameter model laju transmisi TB

dengan konsep epidemi SIR sebagaimana dalam Side [8]

\begin{tabular}{cl}
\hline $\begin{array}{c}\text { Variabel dan } \\
\text { parameter }\end{array}$ & Keterangan \\
\hline$S_{h}$ & Jumlah manusia yang rentan \\
$I_{h}, I_{i}$ & Jumlah manusia yang terinfeksi I dan II \\
$R_{h}$ & Jumlah manusia yang sembuh \\
$N_{h}$ & Konstanta jumlah seluruh populasi manusia \\
$\mu_{h}$ & Rasio kelahiran atau kematian populasi manusia \\
$\beta_{h}$ & Rasio manusia yang rentan \\
$\gamma$ & Rasio manusia yang diduga akan terinfeksi I ke infeksi II \\
$\delta_{h}$ & Rasio manusia yang terinfeksi I ke populasi sembuh \\
$\varphi_{h}$ & Rasio manusia yang terinfeksi II ke populasi sembuh \\
\hline
\end{tabular}

\subsection{Metode Iterasi Variasional}

Metode iterasi variasional (VIM) diperkenalkan oleh He [10] untuk menyelesaikan persamaan diferensial. VIM merupakan hasil modifikasi metode pengali Lagrange yang telah terbukti dapat menemukan solusi yang cepat dan mudah perhitungannya $[10,11]$. Dalam VIM, terdapat tiga konsep utama yang digunakan untuk menyelesaikan suatu persamaan diferensial yaitu pengali Lagrange, fungsi koreksi, dan variasi terbatas [3]. Untuk menyelesaikan sistem persamaan diferensial (1), makalah ini mengikuti tulisan Rangkuti, dkk. [12].

Untuk menggambarkan prosedur dalam metode iterasi variasional, dipandang persamaan diferensial dalam bentuk operator sebagai berikut:

$$
L \mu_{i}(t)+N \mu_{i}(t)=g_{i}(t), \quad i=1,2, \ldots, n .
$$

Di sini, $L$ adalah operator linear, $N$ adalah operator nonlinear, dan $g_{i}(t)$ adalah bentuk persamaan diferensial nonhomogen. Menurut metode iterasi variasional, syarat dari barisan 
$\left(\mu_{i}(t)\right)$ dibuat sedemikian rupa sehingga barisan ini menuju solusi eksak dari model matematika tersebut. Komponen $\mu_{i}(t)$ dapat dihitung dengan fungsi koreksi sebagai berikut:

$$
\mu_{i, n+1}(t)=\mu_{i, n}(t)+\int_{0}^{t} \lambda_{i}\left[L \mu_{i, n}(s)+N \widetilde{\mu_{i, n}(s)}-g_{i}(t)\right] d s .
$$

Di sini, $\lambda_{i}, i=1,2, \ldots, n$ adalah pengali Lagrange yang dapat diidentifikasi secara optimal melalui teori variasional, indeks $n$ menunjukkan hampiran urutan ke- $n, \widetilde{\mu_{l, n}(s)}$ menotasikan variasi terbatas, yaitu $\delta \widetilde{\mu_{l, n}(s)}=0$, dan $\delta$ adalah turunan variasional [11].

Fungsi koreksi dari sistem persamaan diferensial (1) akan diperoleh sebagai berikut:

$$
\begin{gathered}
x(n+1)=x_{n}+\int_{0}^{t} \lambda_{1}\left[\frac{d x_{n}}{d s}-\mu_{h}+\beta_{h} x_{n}+\gamma \beta_{h} \widetilde{x_{n} y_{n}}+\mu_{h} x_{n}\right] d s \\
y(n+1)=y_{n}+\int_{0}^{t} \lambda_{2}\left[\frac{d y_{n}}{d s}-\beta_{h} \widetilde{x_{n}}+\alpha y_{n}\right] d s \\
z(n+1)=z_{n}+\int_{0}^{t} \lambda_{3}\left[\frac{d z_{n}}{d s}-\gamma \beta_{h} \widetilde{x_{n} y_{n}}+\eta z_{n}\right] d s
\end{gathered}
$$

dimana $\widetilde{x_{n}}, \widetilde{y_{n}}$, dan $\widetilde{z_{n}}$ merupakan variasi terbatas yaitu $\delta \widetilde{x_{n}}=0, \delta \widetilde{y_{n}}=0$, dan $\delta \widetilde{z_{n}}=0$. Dari persamaan (4)-(6) didapatkan persamaan berikut:

$$
\begin{gathered}
\delta x(n+1)=\delta x_{n}+\delta \int_{0}^{t} \lambda_{1}\left[\frac{d x_{n}}{d s}-\mu_{h}+\beta_{h} x_{n}+\gamma \beta_{h} \widetilde{x_{n} y_{n}}+\mu_{h} x_{n}\right] d s \\
=\delta x_{n}+\delta \int_{0}^{t} \lambda_{1}\left[\frac{d x_{n}}{d s}-\mu_{h}+\beta_{h} x_{n}+\mu_{h} x_{n}\right] d s \\
\delta y(n+1)=\delta y_{n}+\delta \int_{0}^{t} \lambda_{2}\left[\frac{d y_{n}}{d s}-\beta_{h} \widetilde{x_{n}}+\alpha y_{n}\right] d s=\delta y_{n}+\delta \int_{0}^{t} \lambda_{2}\left[\frac{d y_{n}}{d s}+\alpha y_{n}\right] d s \\
\delta z(n+1)=\delta z_{n}+\delta \int_{0}^{t} \lambda_{3}\left[\frac{d z_{n}}{d s}-\gamma \beta_{h} \widetilde{x_{n} y_{n}}+\eta z_{n}\right] d s=\delta z_{n}+\delta \int_{0}^{t} \lambda_{3}\left[\frac{d z_{n}}{d s}+\eta z_{n}\right] d s
\end{gathered}
$$

Dengan menggunakan integral parsial, persamaan (7)-(9) akan menjadi: 


$$
\begin{gathered}
\delta x(n+1)=\delta x_{n}+\delta \lambda_{1} x_{n}-\int_{0}^{t}\left[\left(x_{n} \delta \lambda^{\prime}{ }_{1}-\delta \lambda_{1}\left(\beta_{h}+\mu_{h}\right) x_{n}\right)+\delta \lambda_{1} \mu_{h}\right] d s \\
\delta y(n+1)=\delta y_{n}+\delta \lambda_{2} y_{n}-\int_{0}^{t}\left[\delta \lambda^{\prime}{ }_{2} y_{n}\right] d s+\int_{0}^{t}\left[\alpha \delta \lambda_{2} y_{n}\right] d s \\
\delta z(n+1)=\delta z_{n}+\delta \lambda_{3} z_{n}-\int_{0}^{t}\left[\delta \lambda^{\prime}{ }_{3} z_{n}\right] d s+\int_{0}^{t}\left[\eta \delta z_{n}\right] d s
\end{gathered}
$$

atau

$$
\begin{gathered}
\delta x(n+1)=\delta x_{n}\left(1+\lambda_{1}\right)-\int_{0}^{t}\left[\left(\left(\lambda_{1}^{\prime}-\left(\beta_{h}+\mu_{h}\right) \lambda_{1}\right) x_{n} \delta\right)+\delta \lambda_{1} \mu_{h}\right] d s \\
\delta y(n+1)=\delta y_{n}\left(1+\lambda_{2}\right)-\int_{0}^{t}\left[\left(\lambda^{\prime}{ }_{2}-\lambda_{2} \alpha\right) \delta y_{n}\right] d s \\
\delta z(n+1)=\delta z_{n}\left(1+\lambda_{3}\right)-\int_{0}^{t}\left[\left(\lambda^{\prime}{ }_{3}-\eta\right) \delta z_{n}\right] d s
\end{gathered}
$$

Dengan demikian, untuk setiap variasi $\delta x_{n}, \delta y_{n}, \delta z_{n}$ dan $\delta x_{n}^{\prime}, \delta y_{n}^{\prime}, \delta z_{n}^{\prime}$ diperoleh kondisi stasioner sebagai berikut:

$$
\begin{array}{cc}
\delta x_{n}:\left.\left(1+\lambda_{1}(t)\right)\right|_{s=t}=0 & \delta x_{n}:\left.\left(\lambda^{\prime}{ }_{1}-\left(\beta_{h}+\mu_{h}\right) \lambda_{1}\right)\right|_{s=t}=0 \\
\delta y_{n}:\left.\left(1+\lambda_{2}(t)\right)\right|_{s=t}=0 & \delta y_{n}:\left.\left(\lambda^{\prime}{ }_{2}-\lambda_{2} \alpha\right)\right|_{s=t}=0 \\
\delta z_{n}:\left.\left(1+\lambda_{3}(t)\right)\right|_{s=t}=0 & \delta z_{n}:\left.\left(\lambda^{\prime}{ }_{3}-\eta\right)\right|_{s=t}=0
\end{array}
$$

Solusi dari persamaan-persamaan (16) di atas adalah sebagai berikut:

$$
\begin{array}{lc}
\lambda_{1}(t)=-1 & \lambda_{1}(s)=-e^{\left(\beta_{h}+\mu_{h}\right)(s-t)} \\
\lambda_{2}(t)=-1 & \lambda_{2}(s)=-e^{\alpha(s-t)} \\
\lambda_{3}(t)=-1 & \lambda_{3}(s)=-1+\eta(s-t)
\end{array}
$$

Substitusi nilai penggali Lagrange (17) ke dalam persamaan (4)-(6) menghasilkan skema iterasi variasional:

$$
x(n+1)=x_{n}-\int_{0}^{t}\left[\frac{d x_{n}}{d s}-\mu_{h}+\beta_{h} x_{n}+\gamma \beta_{h} x_{n} y_{n}+\mu_{h} x_{n}\right] d s
$$




$$
\begin{gathered}
y(n+1)=y_{n}-\int_{0}^{t}\left[\frac{d y_{n}}{d s}-\beta_{h} x_{n}+\alpha y_{n}\right] d s \\
z(n+1)=z_{n}-\int_{0}^{t}\left[\frac{d z_{n}}{d s}-\gamma \beta_{h} x_{n} y_{n}+\eta z_{n}\right] d s
\end{gathered}
$$

\section{Hasil dan Pembahasan}

Untuk menyelesaikan sistem persamaan (1) dengan menggunakan metode RK4 dan VIM, diperlukan data awal dan nilai parameter. Penelitian ini mengambil data awal dan parameter seperti yang terlihat dalam Tabel 2.

Tabel 2. Nilai awal dan parameter transmisi TB dari penelitian Side [8] dengan beberapa variasi

\begin{tabular}{cc}
\hline Kondisi Awal dan Parameter & $\begin{array}{c}\text { Nilai Kondisi Awal dan } \\
\text { Nilai Parameter }\end{array}$ \\
\hline$N_{h}$ & 8386763 \\
$S_{h}$ & 8377828 \\
$I_{h}$ & 8000 \\
$I_{i}$ & 939 \\
$R_{h}$ & 4 \\
$x\left(t_{0}\right)=x_{0}$ & $\frac{8377828}{8386763}$ \\
$y\left(t_{0}\right)=y_{0}$ & $\frac{8000}{8386763}$ \\
$z\left(t_{0}\right)=z_{0}$ & 939 \\
$\mu_{h}$ & 8386763 \\
$\beta_{h}$ & 0.000046 \\
$\gamma$ & 0.326666 \\
$\delta_{h}$ & 0.123111 \\
$\varphi_{h}$ & 0.041230 \\
\hline
\end{tabular}

\subsection{Penyelesaian Sistem Transmisi TB Model SIR dengan Metode RK4}

Penyelesaian RK4 diperoleh dengan menggunakan data awal dan nilai parameter yang terdapat pada Tabel 2. Dengan menggunakan program MATLAB dapat diperoleh grafik solusi numerik RK4 sistem transmisi TB model SIR seperti ditunjukkan dalam Gambar 1 untuk rentang waktu [0,500] dan lebih jelasnya pada Gambar 2 untuk rentang waktu [0, 5]. 


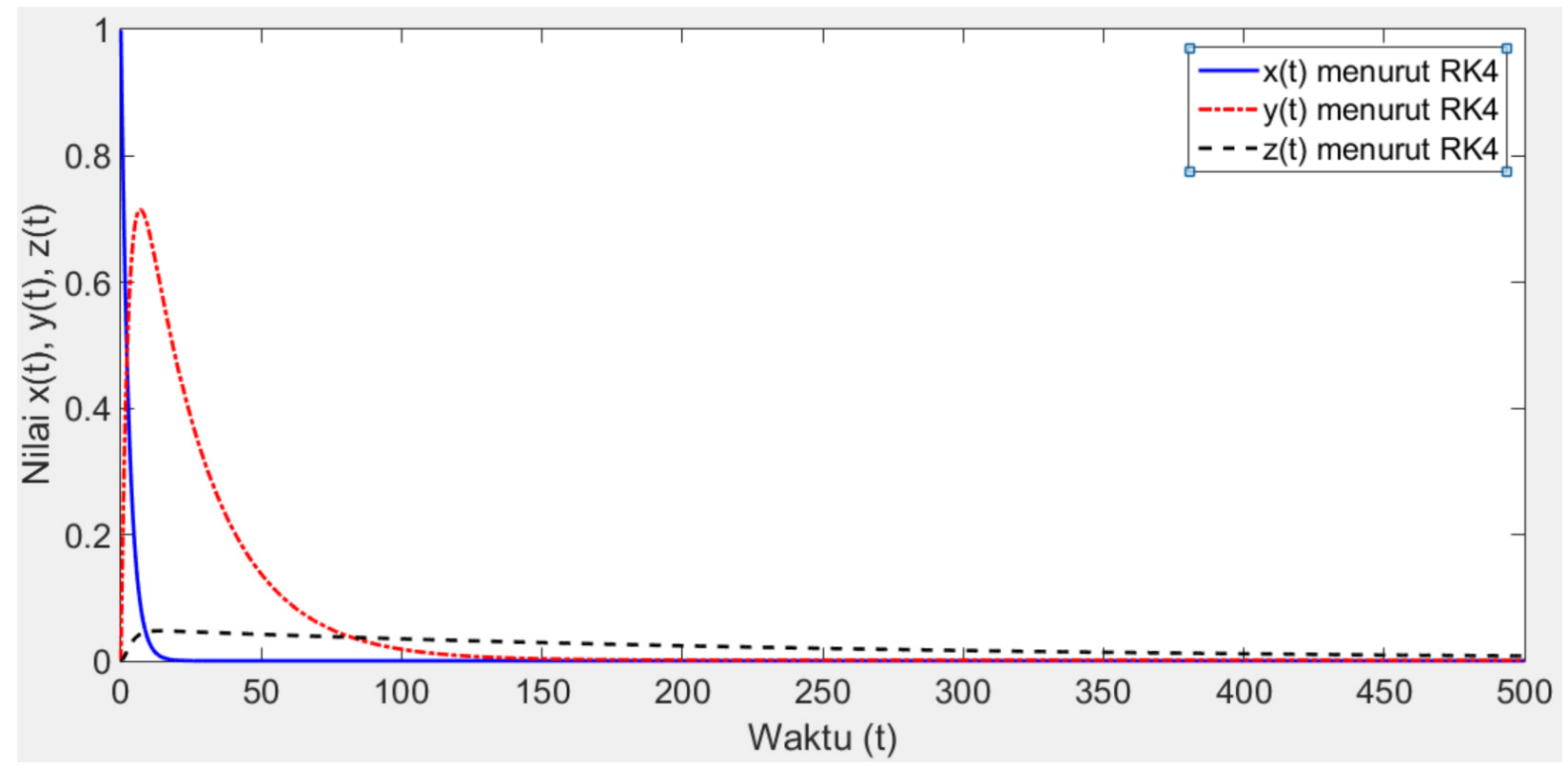

Gambar 1. Grafik solusi sistem transmisi TB menurut metode RK4 untuk waktu $[0,500]$

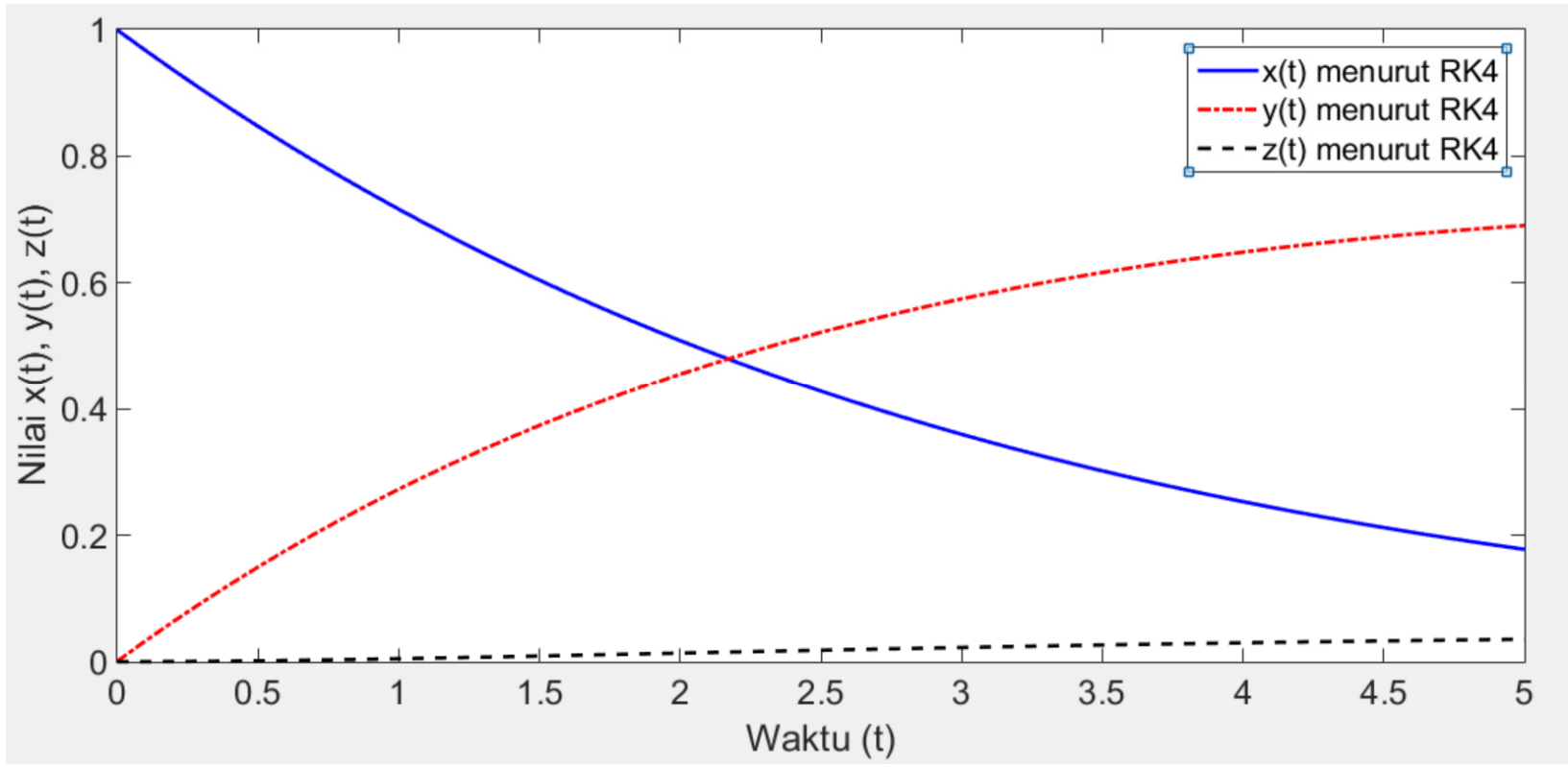

Gambar 2. Grafik solusi sistem transmisi TB menurut metode RK4 untuk waktu [0, 5]

Dengan menerapkan data awal dan nilai parameter pada Tabel 2 pada persamaan (18)-(20), diperoleh solusi numerik dari sistem persamaan diferensial transmisi TB (1). Dengan menerapkan MATLAB, dapat diperoleh grafik solusi VIM lima iterasi dari sistem persamaan diferensial transmisi TB seperti yang dibahas dalam subbagian berikut. 


\subsection{Analisis Hasil Simulasi RK4 dan VIM}

Dari Gambar 1 dan Gambar 2, tampak bahwa semakin banyak manusia yang terinfeksi TB, maka jumlah manusia dari populasi yang rentan terhadap penyakit tersebut akan semakin menurun hingga akhirnya semua anggota populasi terinfeksi juga turun seiring berjalannya waktu. Hal ini berarti bahwa penanganan transmisi TB dapat dikatakan berhasil, sebab populasinya konvergen menuju 100\% sembuh permanen. Berdasarkan hasil perhitungan dari kedua metode numerik yang digunakan, dapat dilihat perbandingan untuk nilai $x(t), y(t)$, dan $z(t)$ dari simulasi seperti yang terlihat pada Gambar 3, Gambar 4, dan Gambar 5.

Dari Gambar 3 sampai dengan Gambar 5, kedua solusi yang dihasilkan oleh metode RK4 dan VIM hampir berhimpit satu sama lain untuk waktu yang cukup kecil. Namun demikian, secara umum, kedua solusi mempunyai perbedaan nilai yang semakin jelas untuk nilai waktu yang semakin besar.

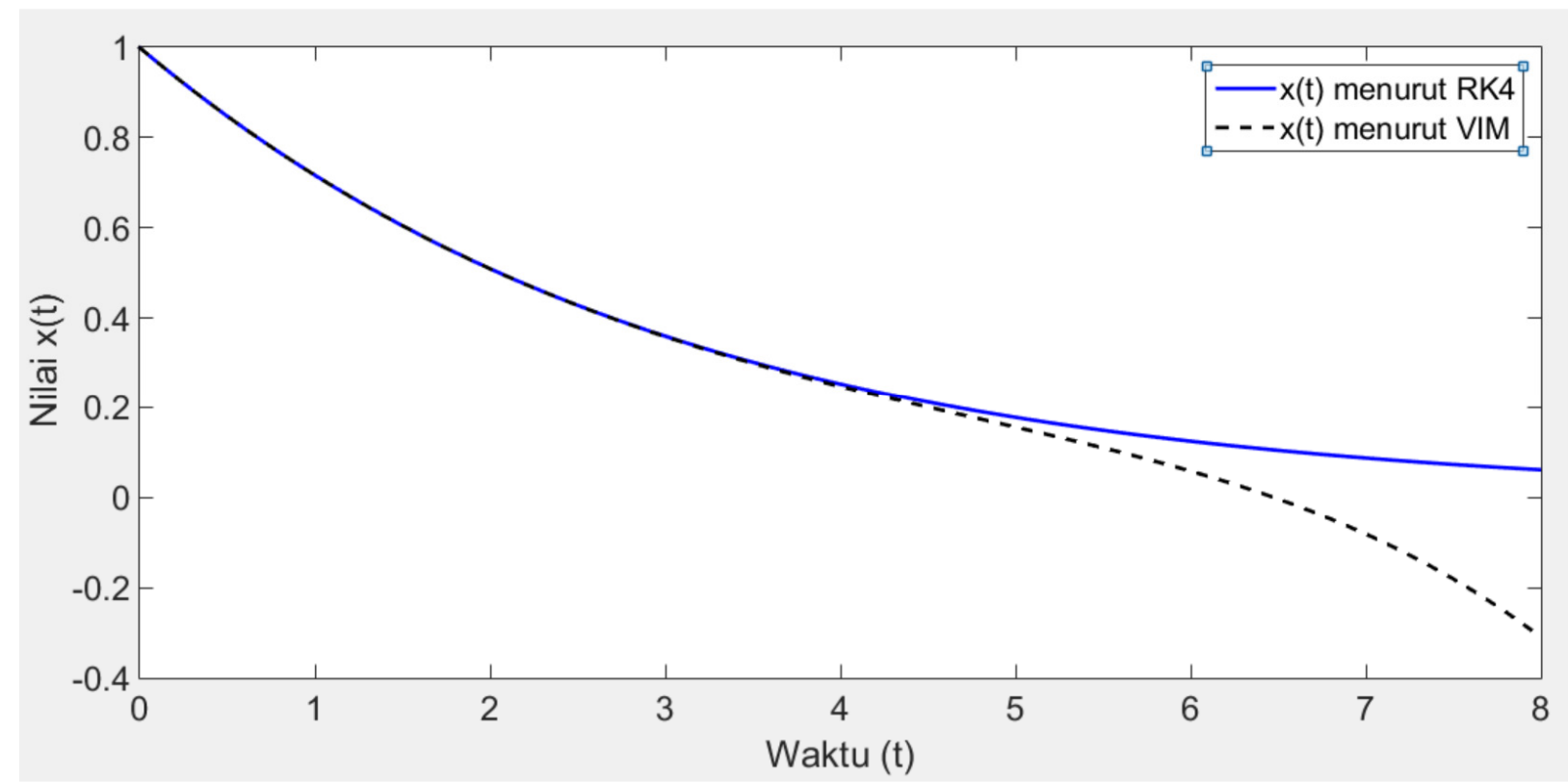

Gambar 3. Grafik solusi $x(t)$ menggunakan metode RK4 dan VIM untuk interval waktu $[0,8]$ 


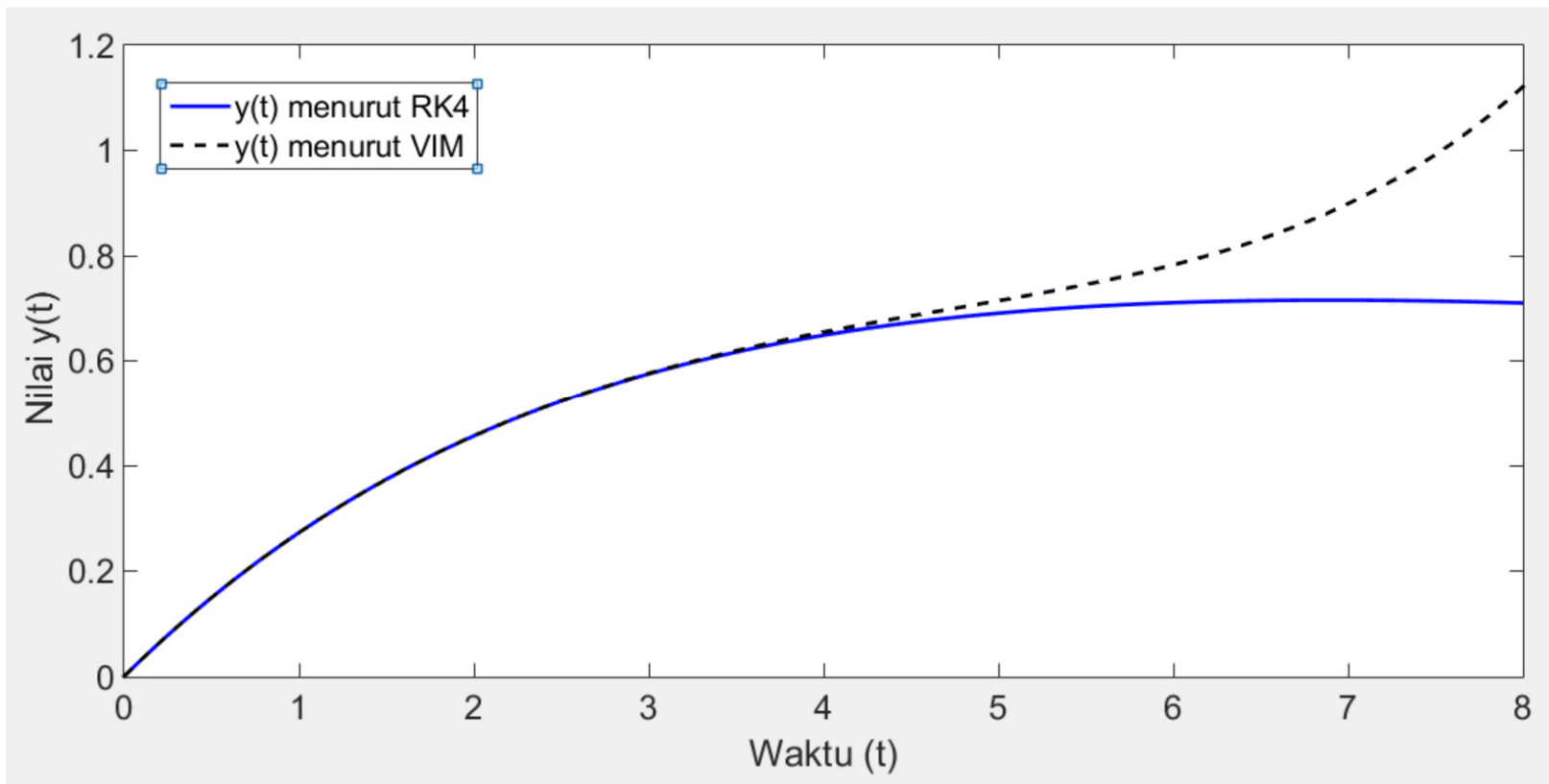

Gambar 4. Grafik solusi $y(t)$ menggunakan metode RK4 dan VIM untuk interval waktu $[0,8]$

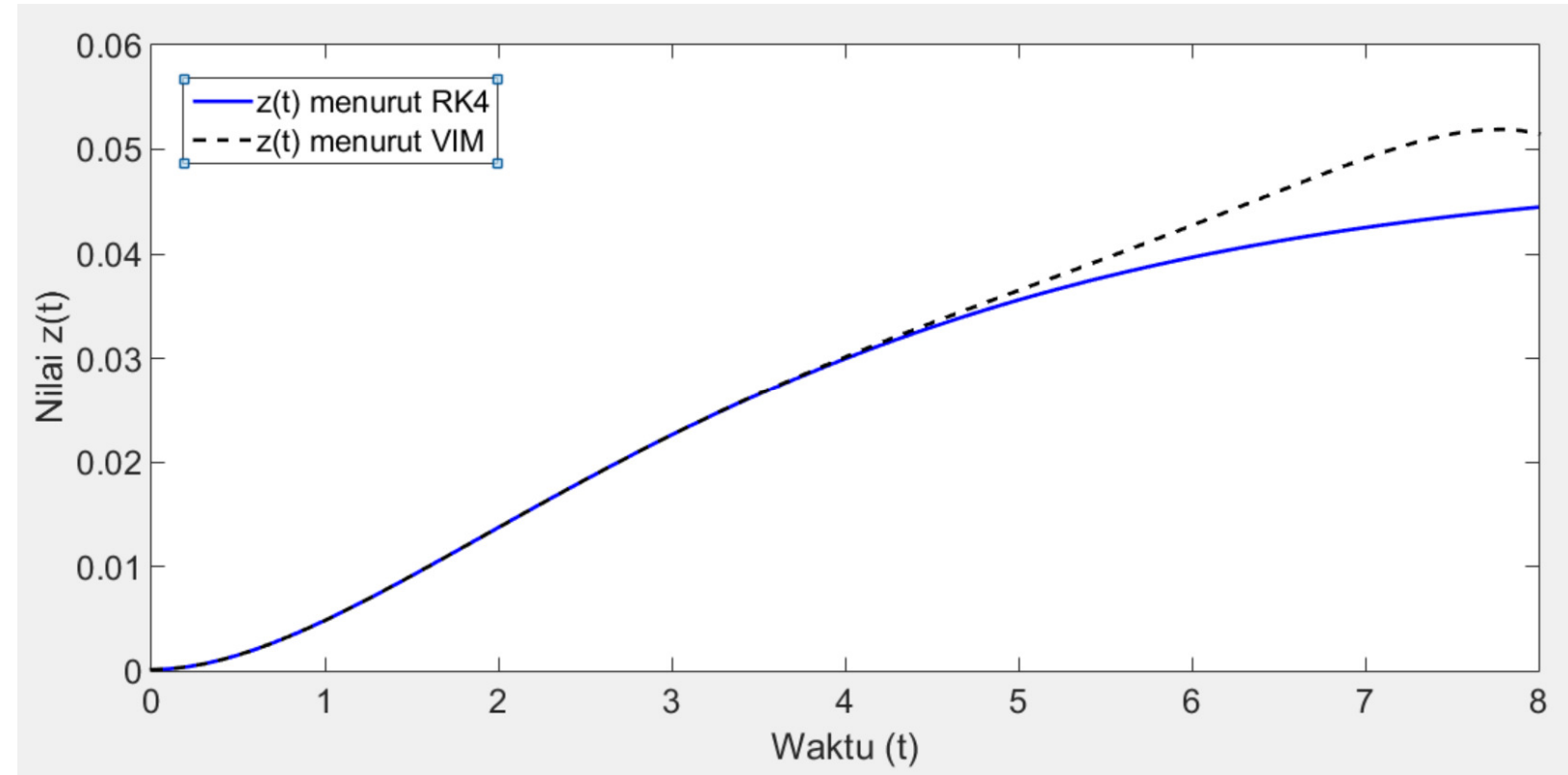

Gambar 5. Grafik solusi $z(t)$ menggunakan metode RK4 dan VIM untuk interval waktu $[0,8]$

Berdasarkan analisis relevansi yang dilakukan oleh Mungkasi dan Wiryanto [13], VIM standar kurang relevan untuk digunakan menyelesaikan model matematika apa bila nilai variabel bebasnya cukup besar. Dalam hal penelitian transmisi TB ini, variabel bebas dalam model adalah variabel waktu. Dengan demikian, solusi yang dihasilkan oleh VIM untuk nilai waktu yang cukup besar adalah kurang realistis, karena metodenya sendiri kurang relevan untuk diterapkan jika nilai waktunya cukup besar [14]. Hal ini dapat dilihat dalam Gambar 3 yang menunjukkan 
bahwa nilai $x(t)$ yang dihasilkan oleh VIM adalah negatif. Selain itu, pada Gambar 4 dapat dilihat bahwa VIM memberikan nilai $y(t)$ yang bernilai lebih dari satu. Hasil ini memberi konfirmasi bahwa VIM standar menghasilkan solusi yang tidak realistis untuk nilai waktu yang cukup besar.

Sebagai catatan, Gambar 5 tidak menunjukkan gejala seperti pada Gambar 3 maupun Gambar 4. Seandainya rentang waktu dari Gambar 5 ini dibuat lebih besar, maka gejala ketidakrealistisan solusi VIM standar akan terlihat seperti halnya yang ditunjukkan dalam Gambar 3 dan Gambar 4. Lebih lanjut, solusi VIM dalam penelitian ini terbatas pada iterasi kelima. Untuk mendapatkan hasil VIM yang lebih realistis di suatu nilai waktu yang cukup besar diperlukan iterasi VIM yang lebih tinggi yang tidak hanya berhenti pada iterasi kelima. Akan tetapi, apabila iterasi diteruskan ke tahap yang lebih tinggi, perhitungan untuk mendapatkan solusi VIM akan semakin panjang.

\section{Simpulan}

Berdasarkan hasil penelitian yang telah dipaparkan, dapat disimpulkan bahwa:

a. Metode RK4 menghasilkan solusi model SIR yang realistis untuk sebarang waktu.

b. Selisih antara solusi RK4 dan solusi VIM sangat kecil untuk nilai waktu yang kecil.

c. Semakin besar nilai waktu yang digunakan dalam VIM standar, solusi yang diperoleh akan menjadi tidak realistis.

\section{$5 \quad$ Ucapan Terima Kasih}

Kedua penulis berterima kasih kepada semua pihak yang terlibat, khususnya Universitas Katolik Indonesia Santu Paulus Ruteng dan Universitas Sanata Dharma Yogyakarta atas pendanaan yang diberikan untuk penelitian ini.

\section{Daftar Pustaka}

[1] R. Haberman, Mathematical Models: Mechanical Vibrations, Population Dynamics, and Traffic Flow, Philadelphia: SIAM, 1998.

[2] M. Y. Li dan Z. Shuai, "Global-Stability Problem for Coupled Systems of Differential Equations on Networks," Journal of Differential Equations, vol. 248, no. 1, pp. 1-20, 2010.

[3] B. D. Yuliyanto dan S. Mungkasi, "Variational Iteration Method for Solving the Population Dynamics Model of Two Species," Journal of Physics: Conference Series, vol. 795, no. 1, art. 012044, 2017. 
[4] F. Brauer dan C. C. Chavez, Mathematical Models in Population Biology and Epidemiology, New York: Springer, 2012.

[5] J. D. Murray, Mathematical Biology: I. An Introduction, New York: Springer, 2002.

[6] F. Shakeri dan M. Dehghan, "Numerical Solution of a Biological Population Model Using He's Variational Iteration Method," Computers and Mathematics with Applications, vol. 54, no. 7-8, pp. 1197-1209, 2007.

[7] J. H. He dan X. H. Wu, "Variational Iteration Method: New Development and Applications," Computers and Mathematics with Applications, vol. 54, no. 7-8, pp. 881894, 2007.

[8] S. Side, "A Susceptible-Infected-Recovered Model and Simulation for Transmission of Tuberculosis," Advanced Science Letters, vol. 21, no. 2, pp. 137-139, 2015.

[9] J. C. Butcher, Numerical Methods for Ordinary Differential Equations, Chichester: Wiley, 2008.

[10] E. Salehpoor, H. Jafari, dan M. A. Afrapoli, "Revised Variational Iteration Method for Solving Systems of Ordinary Differential Equations," Applications and Applied Mathematics: An International Journal, Special Issue no.1, pp. 110-121, 2010.

[11] S. Abbasbandy dan E. Shivanian, "Application of the Variational Iteration Method for System of Nonlinear Volterra's Integro-Differential Equations," Mathematical and Computational Applications, vol. 14, no. 2, pp. 147-158, 2009.

[12] Y. M. Rangkuti, S. Side, dan M. S. M. Noorani, "Numerical Analytic Solution of SIR Model of Dengue Fever Disease in South Sulawesi using Homotopy Perturbation Method and Variational Iteration Method," Journal of Mathematical and Fundamental Sciences, vol. 46, no. 1, pp. 91-105, 2014.

[13] S. Mungkasi dan L. H. Wiryanto, "On the Relevance of a Variational Iteration Method for Solving the Shallow Water Equations," AIP Conference Proceedings, vol. 1707, no. 1, art. 050010, 2016.

[14] G. P. Ningsi, Penerapan Metode Euler, Metode Heun, dan Metode Iterasi Variasional dalam Menyelesaikan Sistem Transmisi Tuberkulosis, Tesis, Yogyakarta: Universitas Sanata Dharma, 2019. 